\title{
LIS NA ZIEMI ULRO. MILOSZ I BECKETT
}

Kiedy Antoni Libera wydał dwa lata temu książkę Godot $i$ jego cień, w „Teatrze” zrecenzowała ją Wanda Zwinogrodzka, tytułując swój tekst $\mathrm{Na}$ ziemi Ulro. Zaskoczyło mnie to wtedy, upłynęło bowiem sporo lat od mojej ostatniej lektury Ziemi Ulro (napisanej w 1977 r.) i przyznam, że nie pamiętałem o ukrytej w eseju Miłosza polemice z Samuelem Beckettem. A przecież kiedyś zaczytywaliśmy się w Ziemi Ulro, także dla mojego pokolenia była to książka kultowa. Libera odnowił swoją autobiograficzną opowieścią obecność Becketta w polskiej kulturze doby ostatniej (tłumaczone przez niego sztuki Irlandczyka grywane są dziś nadzwyczaj rzadko), natomiast Zwinogrodzka - samym tytułem swojej recenzji - przypomniała spór, jaki $\mathrm{z}$ autorem Czekając na Godota od lat 50. aż do śmierci toczył Czesław Miłosz. Jeszcze bowiem w latach 90. pisał do Krzysztofa Myszkowskiego, redaktora „Kwartalnika Artystycznego”: „Wysoko cenię Becketta i dostatecznie go czuję w sobie, żeby bronić się przed nim rękoma i nogami”.

Polemika Miłosza z Beckettem pojawia się w zakończeniu Ziemi Ulro i stanowi punkt dojścia rozważań poety - ostatni kamyk ułożony przez Miłosza w tej eseistycznej mozaice. Jak słyszymy, nie był to kamyk ułożony przypadkowo - polemizując z Beckettem, Miłosz do pewnego stopnia spierał się, a nawet walczył z sobą samym. Przypomina to walkę człowieka z własnym cieniem - że nawiążę znowu do książki Libery - walkę beznadziejną, ale toczoną świadomie i do końca, a przez to heroiczną. Miłosz jednak wolał nie mówić o heroizmie, ale o przebiegłości i sprycie. W potyczce z Beckettem, a dokładniej 
z zapisaną w jego dziełach wizją człowieka i świata, chciał być raczej Odyseuszem niż Hektorem. A tak naprawdę - lisem. Napisał w Ziemi Ulro: „,Beckett] zachowuje się tak, jak ktoś, kto przychodzi do garbusa i zaczyna się nad nim znęcać: «garbus jesteś, garbus, wolisz o tym nie myśleć, to ja postaram się, żebyś myślał». Sam wiem, że jestem garbus, i nie udaję, że nim nie jestem [...] nędzę mojego ludzkiego istnienia znam dobrze, niejeden też raz, kiedy chciało mi się wyć i bić głową w ścianę, zbierałem się do kupy wysiłkiem woli [...], a ten do mnie zwraca się, jakby dokonał odkrycia, $i$ jest $w$ tym jakaś niestosowność, koń uczący lisa jak polować, przy czym to ja jestem lisem, skoro chytrością, fortelem pokonuję w sobie moje cierpienie istoty świadomej".

Mozaika Miłosza składa się z wielu różnych elementów: mamy w niej wspomnienia biograficzne, streszczenia systemów myślowych trzech wizjonerów i poetów: Swedenborga, Blake'a i Oskara Władysława Miłosza, mamy fragmenty poświęcone Adamowi Mickiewiczowi z metafizyczną interpretacją Pana Tadeusza jako poematu o ładzie świata, mamy rozważania na temat Dostojewskiego i Gombrowicza, mamy spór o kształt poezji. A wszystko to pisane w sposób prosty, komunikatywny, językiem bliskim gawędzie czy potocznej rozmowie. ,Ziemia Ulro wyrosła z czystej potrzeby porozumienia się autora z czytelnikiem" - pisze Barbara Koc w rozprawie poświęconej esejowi Miłosza i ma rację. W samej formie tej prozy: jasnej, zrozumiałej, ,nie narażającej nikogo, / autora ni czytelnika, na męki wyższego rzędu" (Ars poetica?), tkwią już pierwsze pierwiastki polemiczne z Beckettem.

Jest przecież Samuel Beckett przedstawicielem tego nurtu awangardowej literatury połowy XX w., która hermetyczną formą poszczególnych dzieł wskazywała na kryzys języka, który oderwał się od rzeczywistości, i wynikający z tego kryzys świadomości ludzi naszych czasów, którzy stracili narzędzie poznania i porozumiewania się ze sobą. Kryzys ten najmocniej objawił się w dramaturgii takich pisarzy, jak właśnie Samuel Beckett czy Eugène Ionesco na Zachodzie i Tadeusz Różewicz czy Helmut Kajzar w Polsce. Miłosz go nie lekceważył, ale uważał za tragiczną przypadłość czasu i ze wszystkich sił starał mu 
się przeciwstawić. Był przecież poetą, który wierzył w możliwość objaśnienia siebie i świata oraz porozumienia $\mathrm{z}$ innymi. Był poetą-tłumaczem we wszystkich znaczeniach tego słowa. Na scenie jego twórczości zjawiają się więc rozmaici poeci, pisarze, filozofowie, dawni i nowi, Zachodu i Wschodu, których poeta dosłownie przekłada, ale i do których czyni dostęp, z którymi rozmawia jak z sobie współczesnymi i nas do tej rozmowy zaprasza. Zasadą jego twórczości jest dia$\log$, czasem polegający na polemice, ale polemice opartej na przekonaniu, że nadal dysponujemy wspólnym systemem pojęć, w ramach którego możemy określić swoje stanowiska. To wyjątkowe w epoce dyskursów równoległych - kulturowego polimonologu. Dlatego tak ważne będą dla nas polemiki Miłosza z Gombrowiczem czy z Różewiczem - pokazują one różnice w świecie, który u Miłosza pozostaje całością. Podobnie jak język, który, choć „obsługuje” wiele różnych światopoglądów, pod wpływem nauki staje się coraz bardziej abstrakcyjny, a pod wpływem mediów wulgarny, nie oderwał się od wspólnego wszystkim doświadczenia i może służyć porozumieniu.

Wśród osób, z którymi dialoguje Miłosz, zjawia się więc Beckett jako „najuczciwszy” - słowo Miłosza - przedstawiciel współczesnej cywilizacji Zachodu, którą poeta nazywa „ziemią Ulro”. Ponieważ Miłosz chciałby nas z tej krainy wyprowadzić, czyni Becketta swoim antagonistą. Nigdy się nie spotkali, ale mogli się spotkać, jakiś czas chodzili przecież ulicami tego samego miasta. „Paryska premiera sztuki Czekajac na Godota odbyła się w Théâtre Babylone w styczniu 1953 r. Wkrótce potem oglądał to przedstawienie Miłosz, patrząc na pękającą ze śmiechu publiczność i konstatując, że rozpacz podana $\mathrm{w}$ formie klaunady prowadzi do zobojętnienia, zaś bohaterami Becketta są istoty całkowicie pozbawione wolnej woli” - pisze Andrzej Franaszek w biografii Miłosza. Felietony wysyłane przez poetę do radia BBC w Londynie świadczą o tym, że śledził twórczość Becketta i oglądał Końcówkę, Ostatniq taśme Krappa oraz Szczęśliwe dni. I właśnie do Koncówki wróci po latach w zakończeniu Ziemi Ulro, posługując się angielskim tytułem utworu - czyli Endgame.

Mottem do swojego eseju Miłosz uczynił słynny dwuwiersz Williama Blake’a, który brzmi następująco: „Jak zwierzę drapieżne w la- 
sach boleści. / W snach Ulro karzą siebie za dobroć ludzką". Tak jak u Blake'a, Ulro jest w jego dziele stanem ducha, którego kształt metaforycznie wyraża obraz upadającej krainy. Jej mieszkańcami są ludzie okaleczeni duchowo - ludzie niekompletni. Żyjący na przełomie XVIII i XIX w. Blake w krainie tej umieszczał uczonych, Bacona, Locke'a, Newtona, intelektualistów, artystów - wszystkich, którzy z nauki uczynili najważniejsze, a w końcu jedyne narzędzie poznania świata. Skąd wzięło się ich okaleczenie? Miłosz tłumaczy je tak: „U Blake'a cztery mityczne postacie tworzą w człowieku rodzinę, której skłócenie doprowadziło do katastrofy". Postacie te reprezentują Ciało z jego pięcioma zmysłami, twórczą Wyobraźnię poszczególnego człowieka, Uczuciowość (miłość i nienawiść), wreszcie Rozum. Złamanie harmonii, skłócenie tej rodziny, bierze się z dominacji Rozumu, który upadł z powodu pychy i oddzielił się od reszty rodziny. „Właściwe są mu bezcielesność, brak uczuć i, co najważniejsze, niedostępne jest mu źródło wszelkich działań Wyobraźni, podświadomość" - pisze dalej poeta. Dominacja rozumu w ludzkim świecie a chodzi nie tylko o poznanie, ale i działanie, budowę zbiorowej świadomości, architekturę wyobraźni, ale także organizację życia, czyli politykę - oznacza dominację racjonalizmu. To na nim został ufundowany światopogląd naukowy, który podważył, a potem wykluczył inne sposoby poznawania, doświadczania i organizowania świata: mityczny i religijny.

Kiedy przy pojęciu ,światopogląd naukowy” stawiamy nazwiska Locke'a czy Newtona, mamy poczucie pewnego anachronizmu - żyjemy przecież w zupełnie innych czasach. Ale we fragmencie poświęconym Beckettowi Miłosz nie przywołuje już naukowców z XVII i XVIII w., ale ich współczesnych następców. Mówi mianowicie o Jacques'u Monodzie, francuskim genetyku, którego teorie stanowią dla poety przykład naukowego radykalizmu dziś. Monod napisał książkę Przypadek i konieczność, opublikowaną na Zachodzie w roku 1970 (w Polsce dzieło zostało wydane w 1979). Esej Monoda traktował o filozofii biologii i spowodował ożywioną dyskusję naukowa, a także filozoficzno-polityczną. Monoda interesowały bowiem związki zachodzące między właściwościami organizmów żywych, pozna- 
nymi na podstawie pierwszych badań molekularnych, a ewolucją tychże organizmów i całego wszechświata. Analiza stworzeń mikro była $\mathrm{w}$ jego książce punktem wyjścia do zbudowania naukowej wizji całego kosmosu. Najważniejsze jednak, że francuski genetyk rozważał wpływ badań naukowych na koncepcje etyczne i polityczne. Współczesne eksperymenty genetyczne to wypełnienie jego hipotez o możliwości tworzenia nowych organizmów, a co za tym idzie o konieczności dostosowania do tych możliwości zasad prawnych. Monod był, jako się rzekło, naukowcem radykalnym, takim, który dla prawdy odkrywanej przez naukowców gotowy był poświęcić reguły i zasady określające życie ludzkie w jego wymiarze duchowym, filozoficznym i etycznym. Odkrycia naukowe obracały je w gruz, na którym Monod - podobnie jak inni współcześni naukowcy - pragnął budować nowy ład. „W literaturze temu radykalizmowi naukowca odpowiada Beckett" - powie Miłosz.

„Jak ulegają zniszczeniu i degradacji istoty żyjące, tak też dzieje się z samym światem (Ziemią, Kosmosem, Bytem)" - pisze w komentarzu do Końcówki Antoni Libera, a jego słowa brzmiąjak wywody Monoda. „Proces ten odbywa się stopniowo i skokowo. Zepsucie kumuluje się, po czym następuje zapaść. $\mathrm{W}$ trakcie przedstawianego zdarzenia mamy do czynienia raczej z «ewolucją» niż «rewolucją». $\mathrm{W}$ przeszłości jednak, i to w miarę niedawnej, miał miejsce właśnie kataklizm, rodzaj gruntownego załamania się dawnego porządku. Albowiem świat «obecny» jest wyraźnie po katas tro fie [podkr. A.L]. Choć nie jest to powiedziane wprost, wiele wzmianek i oznak wskazuje jednak, iż tkwiące «w schronieniu» [...] postaci są, być może, ostatnimi istotami na Ziemi [...]. «Na zewnątrz jest śmierć» - powiada zaraz na początku Hamm".

Naturę katastrofy ukazanej przez Becketta Miłosz w Ziemi Ulro objaśnia następująco:

Beckett, jak zresztą cała jemu współczesna kultura zachodnia, urbi et orbi ogłosił to, co jeszcze w dziewiętnastym wieku znane było tylko nielicznym, co sarkastycznie wyraził Nietzsche, wołając do Europejczyków: „cóż, zabiliście Boga i myślicie, że ujdzie to wam bezkarnie?” Teraz 
W skali masowej nastapiło uświadomienie sobie nowej sytuacji metafizycznej człowieka, którą określa dużymi literami wypisane NIE MA. Żadnego głosu przemawiającego ze wszechświata, żadnego zła i dobra, żadnego spełnienia oczekiwań i żadnego Królestwa. Osoba ludzka dumnie pokazująca na siebie palcem ,ja" też okazała się ułuda, bo to tylko wiązki refleksów okryte jedną epiderma. Miłość okazała się ułuda, przyjaźń okazała się ułuda, bo żeby istniały, musi istnieć jakiś sposób porozumienia, a gdzież on, jeżeli język jest tylko bełkotem utwierdzającym samotność każdego? A cóż ostaje się wśród tego ogromnego NIE MA? Tylko czas, czas absolutny, pędzący znikąd donikąd, mierzony stopniowym zniszczeniem w komórkach organizmu.

Świat konstruowany przez naukę jawi się jako kraina nieskończonych możliwości, coraz dalej przesuwająca swoje granice - wszak wnikamy w atom i podbijamy kosmos - i coraz bardziej pomnażająca swoje zasoby. Jednak rewersem tego świata jest pustynia, świat, w którym degradacji uległ sam byt, świat-fantom, wielkie NIC, które na scenie pokazał Beckett. Łatwo w nie uwierzyć, mając w pamięci zniszczenia II wojny światowej. Europę jednak odbudowano, ale pustka pozostała, o czym świetnie pisał Miłosz na przykładzie Paryża. To miasto na początku lat 50 . było dla niego tak samo ,nierzeczywiste”, jak „nierzeczywisty” był Londyn w Ziemi jałowej Eliota. Beckett $\mathrm{w}$ teatrze urzeczywistnił te pustkę.

Miłosz napisał kilka bardzo ważnych wierszy, których tematem była degradacja samego bytu i wyobrażam sobie, że gdy Clov w Końcówce montuje swoją lunetę i patrzy przez okienko na świat rozciągający się poza schronem, widzi rzeczywistość ujrzaną przez Miłosza w wierszu Economia divina (1973):

Drogom na betonowych słupach, miastom ze szkła i żeliwa, Lotniskom rozleglejszym niż plemienne państwa

Nagle zabrakło zasady i rozpadły się.

Clov wygląda też przez drugie okienko, usytuowane naprzeciw. Mógł przez nie dostrzec to, co Miłosz zobaczył w wierszu Po drugiej stronie (1964): 
[...] Drewniane baraki,

albo jednostopa kamieniczka w polu chwastów, działki kartofli ogrodzone kolczastym drutem.

A grali w niby-karty i był zapach niby-kapusty

i niby-wódka, niby-brud i niby-czas.

Mówiłem, że przecież... ale wzruszali ramionami

albo odwracali oczy. Bo ten kraj nie znał zdziwienia.

Ani kwiatów. Pelargonie w blaszankach uschnięte,

pozór zieleni zakryty lepkim pyłem.

Ani przyszłości. Grały gramofony

powtarzając bez ustanku co nigdy nie istniało.

Pisząc ten wiersz, Miłosz inspirował się obrazem piekła zapisanym przez Emanuela Swedenborga. W wojennym wierszu Przedmieście to piekło wyglądało tak:

Dalej miasto otworzone krwawą cegła,

Jedna sosna za żydowskim domem,

Sypkie ślady i równina aż do końca.

Pył wapienny, toczą się wagony,

A w wagonach czyjaś skarga skamlająca.

Weź mandolinę, na mandolinie

Wygrasz to wszystko

Ech palcem w struny.

Piękna piosenka,

Jałowe pole,

Szklanka wypita,

Więcej nie trzeba.

W tym czasie katastrofizm Miłosza nie karmił się już apokaliptyką, ale obrazami ludzkiej degradacji - jak w Ziemi jałowej. Ostatnim śladem sztuki jest w tym świecie pijacka piosenka i gra na mandolinie.

O grze, a dokładniej o końcu gry mówi Miłosz w podsumowaniu swoich rozważań o Becketcie: „Istotne i, powtarzam, świadczące o wielkości Zachodu, jest wyznanie zrobione przez człowieka samemu sobie, zawarte w jednowyrazowym tytule Becketta: «Endgame». 
I ten koniec zabawy to nie tylko śmierć jednostkowa, bo tę można znieść stoicko. To radykalne stwierdzenie, że wyobraźnia ludzkości, tworząca w ciągu tysiącleci mity religijne, poematy, sny wykute w kamieniu, wizje malowane na drzewie i płótnie, rozczula nas swoją dziecinną wiara, ale możemy tylko myśleć z nostalgią o darze dawno utraconym. Wyobraźnia od XVIII wieku próbowała się bronić, obwarowując się w swoich posiadłościach literatury i sztuki, coraz bardziej wprawiając się w wielowarstwowej ironii, ale nadszedł czas, że została ugodzona od środka i pozbawiona jakiegokolwiek ontologicznego oparcia. Koniec zabawy to koniec literatury i sztuki, a jeżeli one zawsze towarzyszyły cywilizacji, to zarazem koniec cywilizacji”. Artyzm karmi się więc jeszcze końcem wszelkiego artyzmu - powie Miłosz o Becketcie. „Endgame podtrzymuje, na krótko, jeszcze jedną Endgame".

„Gra po grze" Becketta byłaby więc jedyną możliwością istnienia sztuki w świecie po katastrofie? Jeżeli przyjąć światopogląd Becketta za jedyny i ostateczny - owszem, a wiemy już, że ,,endgame after endgame" w postmodernistycznej odmianie tej zabawy może trwać długo. Ale Miłosz buntuje się przeciwko temu i mówi: diagnoza Becketta jest prawdziwa, ale wąska, jego postawa bardzo konsekwentna, ale jednostronna. Bo przecież skoro uświadamiam sobie moje położenie, przekraczam je, ponadto jestem wolny, odróżniam się od miliardów innych ludzi, mam ciało i pięć zmysłów, czuję, pamiętam, jestem skądś, myślę i wyobrażam sobie, umiem porządkować rzeczywistość i nazywać ją, nadal jestem zdolny do tworzenia, w końcu - dysponuję wolą, czyli chcę i czynię. Mogę więc uciec z ziemi Ulro, a przynajmniej żyć jej na przekór, co oznacza - na przekór hegemonii Rozumu, choć nie przeciwko nauce. Obserwując, co dzieje się z człowiekiem w zracjonalizowanym świecie, Miłosza szczególnie dotyka ludzka bierność, jakże charakterystyczna dla bohaterów Becketta. Owych anty-bohaterów, o których poeta powie z sarkazmem ,jarzyno-zwierzęta” i „blade elizejskie cienie”: „dowodem końcowym obezwładniającej właściwości Ulro (cywilizacja przeciwko sobie) jest bierność postaci (niegdyśs «bohaterów») w literaturze" - pisze, a potem przed- 
stawia kilka sposobów na zachowanie czegoś, co nazwałbym po prostu higieną duchową.

Miłosz w Ziemi Ulro praktykuje ją niejako z marszu, co może dezorientować niewtajemniczonych czytelników eseju. Czemu bowiem obok Gombrowicza i Dostojewskiego zjawia się w nim nagle Mickiewicz jako autor Pana Tadeusza? Czemu mają służyć wspomnienia przedwojennego Wilna z jego mieszkańcami? Czemu passus poświęcony zapamiętanym przez poetę $\mathrm{w}$ dzieciństwie pieśniom religijnym? Dlaczego tyle w eseju Miłosza zapamiętanych obrazów, dźwięków, smaków, przedmiotów, uczuć, którymi obrosły klamki, dzwony, zaułki? Można odnieść wrażenie, że wchodząc w dialog z obcymi duchami, Miłosz od czasu do czasu musi znaleźć się wśród duchów go wspierających, że walcząc na obcej ziemi, musi powrócić na ziemię własna, by się wzmocnić. Nawet jeżeli ziemia ta należy do domeny pamięci i wyobraźni, jest realna. Na tym właśnie polega fortel Miłosza, jego lisia przebiegłość. Skoro bowiem ,jaki jesteś, tak i widzisz”, jak pisał Swedenborg, dbaj o siebie!

Czytając z pozoru chaotyczna, bo posklejaną z różnych fragmentów, sylwiczną Ziemię Ulro, z powodzeniem możemy zrekonstruować ukryty w eseju Miłosza kodeks lisa, czyli kilka praktycznych rad dla tych, którzy pragną zachować duchową higienę. Sformułowałbym je następująco. Po pierwsze: pielęgnuj w sobie zamiłowanie do ładu, mimo że wszystko wokół popada w chaos. Po drugie: ćwicz pamięć, by czas nie rządził toba, ale ty czasem. Po trzecie: oddzielaj dobro od zła i trzymaj się dobra, mimo że zło stale przeważa. Po czwarte: uwierz w to, co widzisz, nawet jeżeli ,prawda” naukowa jest inna (Ziemia obraca się wokół Słońca, ale dla nas to Słońce wschodzi i zachodzi - i niech tak zostanie). Po piąte: ze wszystkich sił trzymaj się konkretu, a jeżeli talent ci pozwala, opisz go tak, byś go sobą nie zasłonił. Po szóste: na przekór absurdowi szukaj sensu. Po siódme: jeżeli zarzucą ci naiwność, broń się ironią. Po ósme: działaj.

Ten lisi kodeks życia w krainie Ulro Miłosz ustanowił po to ostatecznie, by „nie poniżać Etre”, czyli bytu, ,nawet w jego formach dotykalnych i ziemskich”. „Dlatego też czcham na teatr Becketta i Ionesco" - pisał rozzłoszczony do Jerzego Turowicza w 1962 r., chyba 
jednak niesłusznie podejrzewając obu pisarzy o nihilizm. Kodeks ten przetłumaczy potem na wiele świetnych wierszy, wśród których znajdujemy pochwałę aktywnego, wiecznie młodego rozumu, który - spersonifikowany, obdarzony najlepszymi cechami charakteru człowieka, pięknem, mocą i nadzieją - okazuje się przeciwieństwem Rozumu Blake'a. Myślę oczywiście o znanym Zaklęciu. Mamy też pochwałę miłości, która jest drogą powrotną do raju, jak w mniej znanym wierszu Po wygnaniu z tomu Nieobjęta ziemia (1988), którego fragment chciałbym zacytować:

Już nie goń. Cicho. Jak miękko deszcz pada

Na dachy tego miasta. Jak wszystko jest

Doskonałe. Teraz, dla was dwojga budzących się

W królewskim łożu pod oknem mansardy.

Dla mężczyzny i kobiety. Albo dla jednej rośliny

Podzielonej na męskość i żeńskość, które tęskniły do siebie.

Tak, to mój podarunek. Nad popiołami.

Na gorzkiej, gorzkiej ziemi. [...]

I wreszcie mamy pochwałę samej rzeczywistości w wielu epifanijnych wierszach Miłosza, choćby w mojej ulubionej Łace z 1994 r.:

Była to łąka nadrzeczna, bujna, sprzed sianokosów,

W nieskazitelnym dniu czerwcowego słońca.

Całe życie szukałem jej, znalazłem i rozpoznałem:

Rosły tu trawy i kwiaty kiedyś znajome dziecku.

Przez na wpół przymknięte powieki wchłaniałem świetlistość.

I zapach mnie ogarnął, ustało wszelkie wiedzenie.

Nagle poczułem, że znikam i płaczę ze szczęścia.

Właśnie tak godzi się ze sobą skłóconą rodzinę człowieczą: ciało, uczucia, wyobraźnię i rozum, choć wydawałoby się, że po końcu „gry” nie jest to już możliwe. 


\begin{abstract}
In the sketch I present Beckett as a representative of western civilisation and a dialogue between Beckett and Czesław Miłosz. A characteristic outcome of this confrontation are the instruction for the habitués of the Urlo Land (Ziemia Urlo): cultivation of love for order, exercising the memory against the flow of time, choice of goodness despite the unmitigated evil, faith in what is visible, love for facts and search for meaning.
\end{abstract}

Transl. Joanna Stolarek 